\title{
Cytoplasmic CD3 Negative
}

National Cancer Institute

\section{Source}

National Cancer Institute. Cytoplasmic CD3 Negative. NCI Thesaurus. Code C162055.

An indication that cytoplasmic expression of the CD3 complex has not been detected in a sample. 